\title{
Protein AF-10
}

National Cancer Institute

\section{Source}

National Cancer Institute. Protein AF-10. NCI Thesaurus. Code C84463.

Protein AF-10 (1027 aa, 109 kDa) is encoded by the human MLLT10 gene. This protein may be involved in the modulation of transcription. 